\title{
Medieval rulers in their own right: case studies of Eleanor of Scotland and Mary of Gueldres
}

Lynn Atkin

\begin{abstract}
Scotland is usually portrayed as being a country that had weak and terrible queens, like Margaret Tudor and Mary Queen of Scots. Saint Margaret is the only queen who is constantly portrayed positively. However, that is not because of her actions as queen consort, but because she was a devote Christian. Scotland is also portrayed for not producing well known or strong female rulers. This essay will examine two contemporary female rulers from the mid-fifteenth century, one from Scotland, Eleanor of Scotland, and one imported to Scotland, Mary of Gueldres. Using these case studies it will be demonstrated that Scotland did produce strong female rulers along with acquiring them.
\end{abstract}

Scotland is often portrayed as being a country that had weak and terrible queens. Margaret Tudor and Mary Queen of Scots are popular examples. Saint Margaret is the only queen who is constantly portrayed positively. However, that is not because of her actions as queen consort, but because she was a devoted Christian. Scotland is also portrayed as not being able to produce well-known or strong female rulers. This essay will examine two contemporary female rulers from the mid-fifteenth century, one from Scotland, Eleanor of Scotland, and one imported to Scotland, Mary of Gueldres. Using these case studies it will be demonstrated that Scotland did produce strong female rulers along with acquiring them. These women are good case studies because of the similarities between the two. Though they differ from one another enough that they should not be seen as being atypical or that their lives were stereotypical for that era. In scholarly sources there is a focus on badly portrayed queens of Scotland because people are more likely to show their discontent for their contemporary rulers. Furthermore, queens like Margaret Tudor or Mary Queen of Scots had connections to other strong interfering rulers, usually English ones, whom affected their influence and rule. Both Mary of Gueldres and Eleanor of Scotland had French influence. However, it did not affect their reigns in a similar fashion to those of Margaret Tudor or Mary Queen of Scots. Mary of Gueldres and Eleanor of Scotland were more typical female rulers. Eleanor of Scotland governed Austria-Tyrol as regent while her husband, Sigismund Archduke of Austria-Tyrol, was away. While Mary of Gueldres had influence at her husband's court, James II of Scotland, and was regent over her son's minority government for three years until her death in 1463. This essay will explore Eleanor of Scotland's influence in Austria-Tyrol concerning her internal policies along with her cultural and court influence. Eleanor will be examined through her own means and ideas along with her relation to her husband and Scotland. Mary of Gueldres' influence over court life and internal politics during her husband's reign will be examined. Then her internal and external politics along with her cultural and structural influence during her son's minority will be surveyed. Mary's influence in these areas is usually scrutinised through the lens of her being a foreigner and how that affected Scotland. This essay will study that along with Mary's personal influence. 


\section{Role of a Queen}

The life of a Medieval Queen was divided into two parts, being the queen consort followed by being the queen regent or queen dowager. In most contemporary literary cases there is no mention of queen regents. A queen was either a consort or a dowager. ${ }^{1}$ Some historians argue that queens did not have political influence during their husbands reign even though they can be seen supporting certain petitions to the king. During the Medieval era the power of the queen was seen as being derived from that of the king. ${ }^{2}$ A queen's role consisted of her relationship to her husband and being his wife more than having a relationship with the state and being a ruler or leader. ${ }^{3}$ Her coronation was not supposed to show her power, but it was meant to enhance the power of the king and her relationship to him, not the state. ${ }^{4}$ The queen was not meant to show intelligence, have a temper or do anything seemingly unfeminine. She was meant to be the embodiment of the Blessed Virgin Mary. ${ }^{5}$ If a queen did not take on this saintly role she was seen as the cause of a king's downfall or as the reason why he could not rule. ${ }^{6}$ A queen was supposed to occupy herself with the private sphere. She was meant to be pure, mothering, nurturing and not at all sexual. ${ }^{7}$ Furthermore, she was expected to concern herself with the spiritual and to do everything in her power to make her husband's rule easier. There was the notion that if the queen behaved, God would ensure an easy rule. That meant that she was supposed to stay out of the way, attend to her duties and not to question her husband's superior authority. ${ }^{8}$ If a queen did not interfere in political affairs the king would be able to make better decisions. She only made his decisions sturdier and improved them with her undying support. By being the ideal queen consort a female ruler was seen as the ideal woman. ${ }^{9}$ When it came to court politics the queen was supposed to be the king's scapegoat or conscience. ${ }^{10}$ This was seen as the main way queens could interfere in politics. If the king had made his opinion clear on a subject but later realized he was wrong the queen would step-in in a ceremonial intervention role. For example, when the petitioners came to the king the queen would kneel with them in support giving the king a way out by saying he was changing his mind because of his wife. ${ }^{11}$

If the king died before the queen and the king's heir was of age, the queen's role changed so that it became related to her son or the heir instead of being the dead king's widow. A queen could also act as regent if her husband left her in charge if he left the country. As queen regent a woman was able to gain some power. It was seen as natural for a queen to be appointed custody of her son for it fit with female ideals of being a mother. However, women with power was seen as unnatural. ${ }^{12}$ As long as she was pious, devoted and not too involved in political affairs she was

\footnotetext{
${ }^{1}$ Fiona Downie, She is but a Woman: Queenship in Scotland 1424-1463 (Great Britain: John Donald, 2006), 21.

${ }^{2}$ Ibid, 21.

${ }^{3}$ Ibid, 3.

${ }^{4}$ Fiona Downie, "Queenship in Late Medieval Scotland," in Scottish Kingship, 1306 - 1542: Essays in Honour of Norman Macdougall, ed. Micheal Brown and Roland Tanner (Great Britain: John Donald, 2008), 234.

${ }^{5}$ Audrey-Beth Fitch, "Maternal mediators: saintly ideals and secular realities in late medieval Scotland," The Innes Review vol. 57 no. 1 (Spring 2006): 1.

${ }^{6}$ Downie, She is but a Woman, 22.

${ }^{7}$ Ibid.

${ }^{8}$ Downie, She is but a Woman, 27.

${ }^{9}$ Ibid, 24

${ }^{10}$ Fitch, 3 .

${ }^{11}$ Downie, "Queenship in Late Medieval Scotland," 236.

${ }^{12}$ Downie, She is but a Woman, 9.
} 
able to keep that power. Furthermore, it is argued that as long as the queen was just a figurehead there would be no problems. ${ }^{13}$ There was a continuing concern about a queen's chastity since she was not supposed to be sexual. ${ }^{14}$ When a female gained too much power, or was no longer seen as chaste she was no longer seen as a fit ruler and should be removed from power. ${ }^{15}$ Since most noble women could not gain power outside of relationships with their husbands and sons, many of them emphasised their international ties and relations in order to secure power and legitimacy. ${ }^{16}$ The final way a queen could exert power during her regency, if she was not allowed have any political say, was by being a patron. ${ }^{17}$ A queen could fund churches, castles, the arts and any number of things without being prosecuted, for it was seen as natural as long as she was using her own funds and not those of the realm.

\section{Eleanor of Scotland}

Eleanor was born in Scotland in 1433 and was the sixth child of James I, King of Scotland, and his wife Joan Beaufort. ${ }^{18}$ She was an elder sister of James II, future King of Scotland. When their father died it was left to James II to arrange marriages for his sisters. Eleanor was invited to France in 1445 along with her sister Joan. ${ }^{19}$ There Charles VII, King of France, took it upon himself to arrange a marriage alliance for Eleanor. Three years later, in 1448, Eleanor of Scotland married Sigismund, the Archduke of Austria-Tyrol. ${ }^{20}$ There is no evidence that Eleanor participated in politics until the appointment of Nicolas Cusanus as Bishop of Brixen in 1450. After his election Eleanor quarrelled with him often. ${ }^{21}$ In 1457 and 1458 her husband was called away and he left her as regent of the country. ${ }^{22}$ After this she became increasingly involved in politics and administration. Also, she was quite involved in translating texts from French to German. $^{23}$ Eleanor died in 1480 without providing an heir. ${ }^{24}$ Throughout her time as Archduchess of Austria-Tyrol Eleanor exhibited her intelligence and learning. She had an active role in internal and external politics along with administration. Furthermore, she had a cultural influence that still affects today. Eleanor is a good case study for she covers all of the aspects of governing. She shows that noble Scottish women had the ability and the learning to rule in their husband's stead.

Eleanor was not a weak, unintelligent woman. She broke from the idea that women did not interfere in their husbands' internal political problems unless asked. When the Bishop of Brixen

\footnotetext{
${ }^{13}$ Ibid, 22.

${ }^{14}$ Fitch, 26.

15 Ibid, 31.

${ }^{16}$ Downie, "Queenship in Late Medieval Scotland," 248.

${ }^{17}$ Ibid, 250.

${ }^{18}$ A.M. Stewart, "The Austrian Connection c. 1450 - 1483: Eleonora and the Intertextuality of Pontus und Sidonia," in Bryght laternis: eassays in the language and literature of Medieval and Renaissance Scotland, ed. J. Derrick McClure and Michael R.G. Spiller, (Scotland: Aberdeen University, 1989), 133.

${ }^{19}$ Ibid.

${ }^{20}$ Elizabeth Bonner, "Charles VII's dynastic policy and the "Auld Alliance": the marriage of James II and Marie de Gueldres”, in The Innes Review vol. 54 no. 2 (Autumn 2003), 158.

${ }^{21}$ Stewart, 134.

22 Stewart, 134.

${ }^{23}$ Priscilla Bawcutt and Bridget Henisch, "Scots Abroad in the Fifteenth Century: The Princess Margaret, Isabella and Eleanor," in Women in Scotland c.1100 - c.1750, ed. Elizabeth Ewan and Maureen M. Meikle (Scotland:

Tuckwell Press, 1999), 52.

${ }^{24}$ Ibid, 50.
} 
died in 1450 the pope, Pope Nicholas V, decided to intervene. He thought that Sigismund needed someone who could give good advice. ${ }^{25}$ The pope's intervention and appointment of Nicholas of Cusa was seen as a violation of the rights of Tyrol. This was the first instance of tension between Nicholas of Cusa and Sigismund. From 1452 to 1455, Nicholas of Cusa encroached on the secular realm and Sigismund's authority. Sigismund knew he could not fight back, for Nicholas was supported by the pope and by Sigismund's cousin, Emperor Frederick III of the Holy Roman Empire. ${ }^{26}$ This tension was what Eleanor had to deal with when her husband was abroad. In 1456 and 1457, Sigismund went to Austria to negotiate with Emperor Frederick concerning the Ottomans. ${ }^{27}$ That year Nicholas of Cusa pushed through many reforms that were against the country's customs, like prohibiting the wearing of armour on holidays related to the church. $^{28}$ Furthermore, Nicholas began buying up some of Sigismund's land. ${ }^{29}$ Sigismund was called away again in 1457. Eleanor was, again, left as regent in his absence. It should be noted that she must have been smart and trustworthy, at least in the eyes of Sigismund, if she was again left in charge while the Archduke was away. When a ruler left his country he did not have to leave his wife in charge. More often a trusted councillor or a group would make decisions in a ruler's absence. Since Eleanor was chosen to run the country in a time of strife and uncertainty it follows that she must have been intelligent and involved in her husband's politics. She must have been in order to continue her husband's politics. During the next year Eleanor began to show herself to be an independent and intelligent Archduchess. Knowing that Pope Calixtus III might impose an interdict on Sigismund because of his fighting with Nicholas of Cusa, Eleanor began to transfer large amounts of land into her name. ${ }^{30}$ This shows Eleanor's initiative. There is no known historical evidence that she was told to transfer the lands in order to preserve them. With her husband abroad there was little means to make contact with her husband and ask for his permission, because it took a long time for orders to arrive. In consequence, Eleanor was left to deal with Nicholas of Cusa alone. Nicholas of Cusa began to assemble an army of his own, and in April 1458 massacred an army regiment outside the Abbey of Sonnenburg. ${ }^{31}$ Eleanor took matters into her own hands and in 1460 she wrote a letter to her brother, King James II of Scotland, requesting diplomatic support. ${ }^{32}$ Eleanor was able to call upon her international relations for help, but King James II had just died, so no help was sent. However, the act from Eleanor of sending a letter to her brother requesting help shows that a woman's power was not just derived from the link to her husband, but also to her family. Finally, Eleanor was quite active in raising the army and getting funding for it. ${ }^{33}$ This army was defense against Nicholas of Cusa and in preparation for attacks from the Ottomans. Eleanor was quite capable when it came to ruling a mountainous territory during a time of political trouble breaking the idea that Scotland could not produce competent female rulers. Along with having political influence Eleanor also influenced the culture of Tyrol.

\footnotetext{
${ }^{25}$ Pardon E. Tillinghast, "Nicholas of Cusa vs. Sigmund of Habsburg: an attempt at post-conciliar church reform," Church History vol. 36 (December 1967): 372.

${ }^{26}$ Ibid, 383.

${ }^{27}$ Stewart, 134.

${ }^{28}$ Stewart, 134.

${ }^{29}$ Tillinghast, 383 .

${ }^{30}$ Stewart, 134.

${ }^{31}$ Tillinghast, 386.

${ }^{32}$ Stewart, 134.

${ }^{33}$ Stewart, 134.
} 
Eleanor was not just an intelligent individual when it came to politics. Her learning and aptitude can also be seen in her court and cultural influences. After her husband's return in 1469 there was no longer a need for Eleanor to be involved in politics, so she turned to literature. ${ }^{34}$ Eleanor became a patron to literature. In 1473, Heinrich Steinhowel dedicated his translation of Boccaccio's book De claris mulieribus to her. ${ }^{35}$ It is said that this dedication occurred because Eleanor was involved "in the early phase of humanism in the Northern Renaissance." ${ }^{36}$ With the wave of humanism there was an urge to translate texts into the vernacular. Not just church texts, but also French ones. ${ }^{37}$ Eleanor is listed as the translator for the text Pontus und Sidonia, which was translated from French to German. It was published in 1483, three years after her death. ${ }^{38}$ It is seen as "a landmark in the history of German prose literature." 39 It is argued that Eleanor may not have translated the text herself, but may have been the patron of the project. ${ }^{40}$ Even if she was only the patron and not the translator, Eleanor made a big contribution to German literature by having this text translated. It helped start the push for the translation of texts with the support of female patrons that did not involve the church or have some religious matter. ${ }^{41}$ Furthermore, this text brought in images of the French court and lifestyle that had been the model for Eleanor's court life at Innsbruck. ${ }^{42}$ With this image still around and influential after her death, it helped carry on her ideas and transformations into future courts. Today this translation is still used as the main translation of this work from French into German. While her culture and court influence was not as great as her political influence, she made changes and showed her intelligence and power which made a difference outside of her husband.

Mary of Gueldres

The other case study is Mary of Gueldres, Queen of Scotland. Mary was the eldest daughter of Arnold, Duke of Gueldres. ${ }^{43}$ She was brought up at the Burgundian court under the influence of her uncle Philip the Good and his wife Isabel of Portugal. ${ }^{44}$ Charles VII, King of France, arranged her marriage to James II of Scotland in $1449 .{ }^{45}$ During the reign of her husband, Mary had some political influence. However, it was only after his death that she wielded more authority. When James II died in 1460, Mary ruled as queen regent for her son's minority government until her death in $1463 .{ }^{46}$ During her time as regent, Mary not only continued on with some of her husband's politics, but also put into action her own ideas. It was during this period that Mary showed her intelligence in the fields of external and internal politics along with developing society. Through the case of Mary of Gueldres it can be seen that queens were not

\footnotetext{
${ }^{34}$ Ibid, 135.

${ }^{35}$ Bawcutt and Henisch, 52.

${ }^{36}$ Stewart, 137.

${ }^{37}$ Ibid.

${ }^{38}$ Ibid, 138.

${ }^{39}$ Bawcutt and Henisch, 52.

${ }^{40}$ Stewart, 138.

${ }^{41}$ Stewart, 137.

42 Ibid, 141.

${ }^{43}$ Norman Macdougall, "Mary (d. 1463)" in Oxford Dictionary of National Biography (Oxford: Oxford University Press, 2004), 1.

${ }^{44}$ Downie, She is but a Woman, 68.

${ }^{45}$ Macdougall, 1.

${ }^{46}$ Ibid, 2.
} 
passive beings. They had the ability to consciously rule in the name of their sons without creating disorder and strife.

Many historians argue that Mary of Gueldres only had political influence because of her continental ties. One thing pointed to is that because of James and Mary's marriage the ScottishBurgundian relationship and treaty was steady from the 1450's until the mid 1460's. ${ }^{47}$ The other alliance that benefited from them marrying was the 'Auld Alliance'. ${ }^{48}$ Their marriage helped solidify the Scottish-Franco relationship because Charles VII helped orchestrate and arrange the marriage. This traditional view of Mary's influence being derived from Burgundy can be seen in some of her court influence. With her ties to Burgundy and the Low Countries, some Scottish musicians went to the continent to learn and improve their profession. ${ }^{49}$ This exchange brought continental culture to Scotland. In addition to that, when Mary came to Scotland there was an influx in cultural growth that reflected the Burgundian court. These were ideas of piety and chivalry. ${ }^{50}$ Some historians see this influence along with the canons that came with her dowry that caused her husband's death as her only sources of influence. Mary was important and influential enough during her husband's reign that a foreign visitor, a Swabian knight Jörg von Ehingen, noted that both James II and Mary presented him with gifts and held dances and feasts in his honour. ${ }^{51}$ Queens were normally assumed to be there along with their husbands, for they planned the festivities and hosted them. However, because Mary was singled out it shows that she made a good impression upon the knight.

Mary of Gueldres played out her queenly role of intervening in petitions to the king. However, it was not always based on James II's need. This way she was able to exert power. In January 1450, Mary not only supported the bishops who were against their land being taken, but she was able to secure more land to act as the payment for her dower. ${ }^{52}$ This land belonged to the Livingstons whom she did not like. Mary was the one who wanted and got their land confiscated. ${ }^{53}$ Another political event that has not been extensively examined is the removal of the Douglases from power and Mary's role. It cannot be a coincidence that before James II and Mary married there was no conflict between James II and the Douglases. It was only from 1449 onward that something changed for James that made him fight back. ${ }^{54}$ This could be because he finally wanted to rule on his own. However, Mary could have functioned in that she came from a country where there was a strong ruler, Charles VII of France. Charles VII ruled for himself and did not have a strong noble family to carry out his politics. Mary could have instilled these ideas into James II when she arrived in Scotland once she realised how little authority James had. Mary would have been quite capable of this. She had lived under France's influence in Burgundy for a great deal of her life and was quite intelligent. It can be argued that Mary was not against the Douglases for in the June parliament of 1451 she interceded on the earl of Douglas' behalf. ${ }^{55}$

\footnotetext{
${ }^{47}$ David Ditchburn, "The Place of Guelders in Scottish Foreign Policy, C. 1449 - C. 1542," in Scotland and the Low Countries, 1124 - 1994, ed.Grant G. Simpson (East Linton: Tuckwell Press, 1994), 67.

48 Bonner, 143.

${ }^{49}$ Katie Stevenson, "Contesting Chivalry: James II and the control of chivalric culture in the 1450s" in Journal of Medieval History vol.33 no.2 (January 2012), 202.

${ }^{50}$ Ibid, 210.

${ }^{51}$ Ibid, 202.

${ }^{52}$ Macdougall, 1.

${ }^{53}$ Rosalind K. Marshall, Scottish Queens (Great Britain: Tuckwell Press, 2003), 62.

${ }^{54}$ Stevenson, 211.

${ }^{55}$ Downie, "Queenship in Late Medieval Scotland," 236.
} 
However, this should be seen as a political tool and this one act does not mean that Mary supported the Douglases and had nothing to do with their removal from power.

James II died in 1460 after having his leg shot off by his own canon during a siege against the English. After his death Mary was given custody of her son, James III, and the realm. ${ }^{56}$ Mary was a quite capable regent. Five days after her husband died, August $3^{\text {rd }} 1460$, she brought her son to the siege at Roxburgh, which the Scots took. James III was then crowned on August $10^{\text {th }} 1460 .^{57}$ These swift actions mark how Mary handled politics in her three years as regent smartly, rapidly and with purpose.

Mary of Gueldres dealt with one external conflict during her regency, the Wars of the Roses. Mary was quite clever in her ability to play one side off the other in order to make territorial gains for Scotland. ${ }^{58}$ Mary had the ability to see which house, the Lancastrian or the Yorkists, it would be more useful to side with. Some historians write that Mary was just continuing the politics of her husband James II. ${ }^{59}$ However, she had to be smart in order to play both sides as she did. Mary of Gueldres first showed support for the house of Lancaster and Queen Margaret of Anjou. Then in 1461 Mary allied Scotland with the Yorkists family because they were supported by her family in Burgundy. ${ }^{60}$ Mary changed sides again in 1463 and lent Margaret Scottish military aid and invaded the north of England in June in hopes of making a final territorial gain. ${ }^{61}$ Along with dealing with the Wars of Roses, Mary also had other international dealings. She received letters and embassies from other countries. She was described by one ambassador "as the leader of the dominant party in government." ${ }^{62}$ Being recognized in such a way by other countries shows her ability to rule proficiently.

One area of policy that was strictly her own idea was her internal development of the country. Mary oversaw the building of her own castle, Castle of Ravencraig, along with its military outfitting. ${ }^{63}$ Along with her castle Mary had other extensive building projects. She funded repairs made to Falkland and Stirling and she funded the building of the Trinity collegiate church and hospital. ${ }^{64}$ By undertaking these projects Mary promoted continental values. She was able to encourage principals and cultural standards that were important to her. ${ }^{65}$ This way, after her death her ideas would continue, for she took part in the organisation of every part of the church and hospital. It was through this patronage that Mary was able to really make a difference and show her status as a queen regent who was on the same playing level as kings. ${ }^{66}$ With all the changes and improvements she began during her time as regent it would have been interesting to see if she had lived more than three years, until 1463, what more she could have done for Scotland.

\footnotetext{
${ }^{56}$ Ibid, 245.

${ }^{57}$ Macdougall, 2.

58 John A. Wagner, Encyclopedia of the Wars of the Roses, (Santa Barbara: ABC-CLIO, 2001), 162.

${ }^{59}$ Marshall, 66.

${ }^{60}$ Wagner, 162.

${ }^{61}$ Ibid, 162.

${ }^{62}$ Downie, "Queenship in Late Medieval Scotland," 245.

${ }^{63}$ Ibid, 245.

${ }^{64}$ Ibid, 250

${ }^{65}$ Ibid.

${ }^{66}$ Downie, "Queenship in Late Medieval Scotland,” 250.
} 


\section{Conclusion}

Female rulers in Europe in the Medieval era have not always been portrayed positively. Their power was thought to be linked to that of their husbands or sons. Many historians argue that they could not have held power on their own for it would have damaged their image of being the Blessed Virgin Mary too much and would have led to the demise of their husbands. The female rulers coming and going from Scotland are perceived no differently. In a lot of cases noble Scottish women, those who came or left, are even more harshly judged. The queens that are studied the most are Margaret Tudor, Mary, Queen of Scots and Saint Margaret. The first two are portrayed horribly because of their circumstances. Saint Margaret is seen as the one and only exception. However, all Scottish ruling women should not be based off of those three. Eleanor of Scotland, Archduchess of Austria-Tyrol was a capable regent while her husband was away from 1457 to 1469. She was able to control unstable internal politics and deal with conflict. Furthermore, she had a great cultural impact on German society with her patronage to the arts. Mary of Gueldres not only had foreign influence during her husband's reign, King James II of Scotland, but she also had cultural and political influence. After her husband died in 1460, Mary of Gueldres became the queen regent of her son's minority government. She was quite capable of dealing with internal and foreign politics. Finally, Mary helped fund and develop Scotland's fortifications and values. Both these women help complete the perspective of female rulers at that time. Generalisations about Scottish female rulers, in the country or outside of it, should be re-examined, for these women were more capable then what many historians think.

\section{Bibliography}

\section{$\underline{\text { Secondary Sources }}$}

Bawcutt, Priscilla and Bridget Henisch. "Scots Abroad in the Fifteenth Century: The Princess Margaret, Isabella and Eleanor." In Women in Scotland c.1100-c.1750, edited by Elizabeth Ewan and Maureen M. Meikle, 45 - 55. Scotland: Tuckwell Press, 1999.

Bonner, Elizabeth. "Charles VII's dynastic policy and the 'Auld Alliance': the marriage of James II and Marie de Gueldres." The Innes Review vol. 54 no. 2 (Autumn 2003): 142 - 185.

Ditchburn, David. "The Place of Guelders in Scottish Foreign Policy, C. 1449 - C. 1542.” In Scotland and the Low Countries, 1124 - 1994, edited by Grant G. Simpson, 59 - 75. East Linton: Tuckwell Press, 1996.

Downie, Fiona. She is but a Woman: Queenship in Scotland 1424 - 1463. Great Britain: John Donald, 2006.

Downie, Fiona. "Queenship in Late Medieval Scotland.” In Scottish Kingship, 1306 - 1542: Essays in Honour of Norman Macdougall, edited by Micheal Brown and Roland Tanner, 232 - 254. Great Britain: John Donald, 2008.

Fitch, Audrey-Beth. "Maternal mediators: saintly ideals and secular realities in late medieval Scotland." The Innes Review vol. 57 no. 1 (Spring 2006): 1 - 35. 
Macdougall, Norman. James III. Edinburgh: John Donald Publishers LTD, 1982.

Macdougall, Norman. "Mary (d. 1463)." In Oxford Dictionary of National Biography. Oxford: Oxford University Press, 2004.

Marshall, Rosalind K. Scottish Queens. Great Britain: Tuckwell Press, 2003.

Stevenson, Katie. "Contesting Chivalry: James II and the control of chivalric culture in the 1450s." Journal of Medieval History vol. 33 no. 2 (January 2012): 197 - 214.

Stewart, A. M. "The Austrian Connection c. 1450 - 1483: Eleonora and the Intertextuality of Pontus und Sidonia." In Bryght laternis: eassays in the language and literature of Medieval and Renaissance Scotland, edited by J. Derrick McClure and Michael R.G. Spiller, 129 149. Scotland: Aberdeen University, 1989.

Tillinghast, Pardon E. "Nicholas of Cusa vs. Sigmund of Habsburg: an attempt at post-conciliar church reform." Church History vol. 36 (December 1967): 371 - 390.

Wagner, John A. Encyclopedia of the Wars of the Roses. Santa Barbara: ABC-CLIO, 2001. 